\title{
Exploring the Antecedents of English Speaking Performance: An Empirical Study on Students in Vietnam
}

\author{
Minh-Nho Vo Thi ${ }^{1}$, Ha Hoang,"* \\ ${ }^{1}$ Department of Research and International Cooperation, University of Foreign Language Studies - The University of Danang \\ (UFLS-UD), Vietnam \\ ${ }^{2}$ Faculty of Business Administration, University of Economics - The University of Danang, Vietnam
}

Received March 5, 2020; Revised March 26, 2020; Accepted April 24, 2020

Copyright $\odot 2020$ by authors, all rights reserved. Authors agree that this article remains permanently open access under the terms of the Creative Commons Attribution License 4.0 International License

\begin{abstract}
With the continuous development of globalization, English-speaking skill becomes important not particularly in Vietnam but also to all the countries not belonging to the English-speaking regions. In the Fourth Industrial Revolution (IR 4.0), with the development of technology, the new achievements can support three essential skills of language learning-which are Reading, Writing and Listening. However, with speaking skills, it can take a long time for the new technology to play an efficient role in communication between people. In fact, many language learners find it difficult to express themselves in spoken language, and each student has their own problems. The purpose of this study was to explore the factors affecting the English-speaking performance of students from Danang City, Vietnam. We systematized relevant studies to build a scale with 40 indicators to measure 14 independent variables. Based on results from data analysis using SPSS software, we discovered four groups of factors that affect students' English-speaking performance. The study contributed important quantitative evidence on the impact of listening and pronunciation skills on students' ability to speak English. We also quantify other groups of variables that have a significant effect on speaking competence, such as vocabulary and grammar, confidence, and nonverbal communication. Based on the findings, we proposed some suggestions to improve students' English speaking proficiency.
\end{abstract}

Keywords Learning Sciences, Communicative Competence, Speaking Performance, Factors, Vietnamese Students

\section{Introduction}

Teaching and learning foreign languages is one of the major concerns of universities. Along with increasing international integration, foreign languages are both a challenge and an opportunity for Vietnamese students in particular and students from non-English-speaking countries. In the trend of innovating learner-centered teaching methods, learning the characteristics of learners plays a fundamental role to innovate and apply successfully to improve the effectiveness of foreign teaching and learning.

A lot of research has discussed the importance of English-speaking skills and their impact. Baker and Westrup shed light on the fact that speaking skills have a positive impact on students in terms of education and careers [1]. A variety of factors can influence students' speaking skills, from performance conditions (time pressure, planning, performance standards and level of support), emotional factors (confidence and anxiety), the ability to hear and respond during conversations, as pointed out in the studies of Nation and Newton [2]. Knowledge of topics' discussion also affects students' ability to speak English [3]. The authors believe that understanding the topic has a good effect on speech efficiency. Many other studies have also included factors such as teacher feedback, inhibition, lack of knowledge about the subject being spoken, using native language $[1,4]$.

A study of Samira Al Hosni has pointed out that speaking difficulties can be key challenges to learn and communicate effectively a foreign language. The students, no matter how much they know about the English language, still encounter many speaking problems. Many researches have indicated that oral language development has largely 
been neglected in the English classroom, and most of the time, oral language is used more by teachers than by students. However, oral language, even as used by the teacher, hardly ever functions as a means for students to gain knowledge and explore ideas [5].

Another type of learning difficulties faced by the students is lack of motivation for speaking English. Many learners do not find a real need to learn or speak English. Actually, motivation is the essential factor which determines whether a student embarks in a task or not, how much energy this learner devotes to it, and how long he or she preservers. The advance of speaking skills can only occur if learners have the motivation and dare to express their own identity and relate with the people around them when they have an opportunity [6].

The lack of a target language environment or good learning environment can be considered another problem, which of course results in a lack of involvement in real-life situations. Not allowing students to participate in communication can be another reason for speaking difficulties. Furthermore, language is best learned when the learners' attention is focused on understanding, saying and doing something with that language, and not when their attention is focused explicitly on linguistic features [7].

We all know that the most important goal of teaching English is to help students can use English effectively and accurately in communication. But there is an acknowledged fact that in the current teaching and learning of foreign languages, students can read and understand well, but this does not mean saying well, even though the highest purpose of learning a foreign language is to communicate between person to person. In learning foreign languages, speaking seems to be the most important and most difficult skill to develop, we call those who know a language are "speakers of that language" [4]. Studies in the new approach to language learning have shifted the focus from teaching to achieve language accuracy to teaching fluency in communication and from teaching language forms to teach effective communication [8].

To help students improve their speaking skills, we realize that lecturers need to know the factors affecting their English-speaking skills to provide appropriate solutions, thereby helping students improve their level of speaking. However, this research direction has not received adequate attention, especially quantitative studies. We conducted this study in a very distinctive context of Danang City, Vietnam where the trend of learning foreign languages, especially English, has grown strongly to meet and catch up with the needs of the local tourism industry.

\subsection{Objectives}

This study identifies the factors affecting students' English-speaking efficiency, proposing solutions to improve the effectiveness of teaching and learning English speaking skills in Danang City, Vietnam.

\subsection{Contributions}

- Our research has proven the importance of listening and pronunciation skills in improving English speaking efficiency of students.

- This is the first study in Danang on the factors that affect students' English-speaking efficiency quantitatively, offering solutions to improve the teaching and learning of foreign languages.

- The study systematized relevant studies to build a scale with 40 indicators to measure 12 independent variables. Based on results from data analysis using SPSS software, we discovered four groups of factors that affect students' English-speaking performance.

\section{Methods}

\subsection{Questionnaire Composition}

This section describes the methods in collecting and processing data used in this study.

From the synthesis of research done on the factors that affect speaking skills, we have built a 5-point Likert Scale questionnaire, from 1-Strongly Disagree to 5-Strongly Agree. 40 indicators were included in this questionnaire to measure 12 independent groups of variables that can affect English speaking efficiency of students. Data analysis results will help to determine which variables can influence the dependent group of 5 indicators, measuring students' ability to speak English.

The subjects surveyed are students of various specialties in Danang City, Vietnam. Information about Research Design is described in Table 1. We used a convenient sampling method to collect data. Questionnaires are sent directly to respondents. We obtained more than 217 valid responses. Cronbach alpha reliability and exploratory factor analysis (EFA) method are used to test the scales. The data was processed and analyzed using SPSS software version 23. According to Peterson, a scale of acceptable and good evaluation requires two conditions simultaneously. Cronbach's Alpha coefficient of the overall is greater than 0.6 and the correlation coefficient through the total variable (Corrected Item-Total Correlation) is greater 0.3 [14].

Table 1. Research Design

\begin{tabular}{|l|l|}
\hline Classification & Item \\
\hline Target & Students in Danang City, Vietnam \\
\hline Sample & Random sampling with equal distribution \\
\hline Period & $08.2019-01.2020$ \\
\hline Size & 217 \\
\hline
\end{tabular}




\subsection{Analysis Method}

We analyzed data collected in this study as follows through the coding process using IBM SPSS statistic version 23.0. The software name originally stood for Statistical Package for the Social Sciences (SPSS). SPSS is a specialized program for processing primary information - information collected directly from research subjects. This software is designed to solve business and research problems through ad hoc analysis, hypothesis testing, geospatial analysis and predictive analytics. Organizations use SPSS Statistics to understand data, analyze trends, forecast and plan to validate assumptions, and drive accurate conclusions. An advantage of this software is providing a data management system and statistical analysis capability with a user-friendly graphical interface including description menu and simple dialog boxes. It is also used by education researchers, survey companies, health researchers, government, data miners, and others. The original SPSS manual [9] has been described as one of "sociology's most influential books» for allowing ordinary researchers to do their own statistical analysis [10].

In our research, first, we conducted a reliability analysis to ensure measurement models and overall validity result of scale is supported. Second, a Linear Regression Model was established and analyzed to examine the effect of the variables on the English-speaking performance of students.

\section{Results}

\subsection{Validity Verification of Scale (Exploratory Factor Analysis)}

Exploratory factor analysis (EFA) helps in reducing large number of indicator variables into limited set of factors based on correlations between variables. On the scale of the independent variables, the overall Cronbach's alpha coefficient is equal to $0.883>0.6$, which is satisfactory. Table 2 shows the results of the Validity verification of scale of independent Variables. After eliminating the invalid variables, the results show that the following 14 independent variables meet the research requirements and will be included in the rotation matrix analysis.

The dependent variable group reflects the ability to speak English after removing 2 unsatisfactory indicators, the data processing results show that all remaining indicators as shown in the table 3 are qualified to include in the matrix rotation analysis $($ Cronbach's Alpha $=0.862>$ 0.6 and all indicators have Corrected Item-Total Correlation>0.3)

Table 2. Validity verification of scale (Independent Variables)

\begin{tabular}{|c|c|c|c|c|c|}
\hline & & $\begin{array}{c}\text { Scale Mean if Item } \\
\text { Deleted }\end{array}$ & $\begin{array}{c}\text { Scale Variance if Item } \\
\text { Deleted }\end{array}$ & $\begin{array}{c}\text { Corrected Item-Total } \\
\text { Correlation }\end{array}$ & $\begin{array}{c}\text { Cronbach's Alpha if } \\
\text { Item Deleted }\end{array}$ \\
\hline \multirow{2}{*}{$\mathrm{VO}$} & VO1 & 38.63 & 69.513 & .527 & .876 \\
\hline & VO3 & 38.10 & 69.866 & .448 & .880 \\
\hline \multirow{2}{*}{ GR } & GR1 & 38.24 & 68.042 & .555 & .875 \\
\hline & GR2 & 38.70 & 68.859 & .493 & .878 \\
\hline \multirow{2}{*}{$\mathrm{CO}$} & $\mathrm{CO} 1$ & 38.38 & 69.116 & .433 & .882 \\
\hline & $\mathrm{CO} 2$ & 38.43 & 67.940 & .580 & .874 \\
\hline \multirow{3}{*}{ LS } & LS1 & 38.51 & 66.621 & .659 & .870 \\
\hline & LS2 & 37.65 & 67.517 & .581 & .874 \\
\hline & LS3 & 37.67 & 67.443 & .623 & .872 \\
\hline \multirow{2}{*}{$\mathrm{NC}$} & $\mathrm{NC} 1$ & 37.71 & 70.946 & .441 & .880 \\
\hline & $\mathrm{NC} 2$ & 38.26 & 70.046 & .489 & .878 \\
\hline \multirow{3}{*}{ PR } & PR1 & 38.12 & 66.754 & .665 & .870 \\
\hline & PR2 & 37.92 & 67.054 & .629 & .871 \\
\hline & PR3 & 37.83 & 67.411 & .653 & .870 \\
\hline
\end{tabular}

Note: VO: Vocabulary, GR: Grammar, CO: Confidence, LS: Listening Skill, NC: Non-verbal Communication, PR: Pronunciation

Table 3. Validity verification of scale (Dependent Variable)

\begin{tabular}{|c|c|c|c|c|c|}
\hline & & $\begin{array}{c}\text { Scale Mean if Item } \\
\text { Deleted }\end{array}$ & $\begin{array}{c}\text { Scale Variance if Item } \\
\text { Deleted }\end{array}$ & $\begin{array}{c}\text { Corrected Item-Total } \\
\text { Correlation }\end{array}$ & $\begin{array}{c}\text { Cronbach's Alpha if } \\
\text { Item Deleted }\end{array}$ \\
\hline \multirow{3}{*}{ SS } & SS1 & 5.58 & 3.532 & .739 & .806 \\
\cline { 2 - 6 } & SS2 & 5.12 & 3.760 & .705 & .837 \\
\cline { 2 - 6 } & SS3 & 5.67 & 3.528 & .773 & .774 \\
\hline
\end{tabular}




\subsubsection{Factor Analysis on Factors Affecting}

Table 4. KMO and Bartlett's Test

\begin{tabular}{|c|c|c|}
\hline \multicolumn{2}{|c|}{ KMO Measure of Sampling Adequacy. } & .842 \\
\hline \multirow{3}{*}{$\begin{array}{c}\text { Bartlett's Test of } \\
\text { Sphericity }\end{array}$} & Approx. Chi-Square & 1228.064 \\
\cline { 2 - 3 } & df & 91 \\
\cline { 2 - 3 } & Sig. & .000 \\
\hline
\end{tabular}

Note: KMO: Kaiser-Meyer-Olkin

The KMO coefficient (Kaiser-Meyer-Olkin) is an indicator used to consider the suitability of factor analysis. The value of KMO must reach a value of 0.5 or higher $(0.5 \leqslant$ KMO $\leqslant 1)$ which is a sufficient condition for factor analysis to be appropriate. If this value is less than 0.5 , factor analysis is likely to be inappropriate for the study data set. In the Table 4, the KMO analysis on factors affecting shows that $\mathrm{KMO}=0.842$ and Barlett sphericity verification ( $\mathrm{df}=91, \mathrm{p}=0.000$ ). In the factor analysis, the factor loading of related factors is based on 0.5 and more, and 4 factors with an eigenvalue of 1.0 or more were extracted. The total variance explanation power explaining the factors is $66.07 \%$ as shown in Table 5 securing the validity of measurement items to some extent. It can be concluded that $66.07 \%$ of the change in factors is explained by the observed variables. After that, analyzing the rotation matrix has divided the indicators into 4 groups of factors affecting English speaking skills. The results of Rotated Component Matrix are presented in Table 6

Table 5. Total Variance Explained

\begin{tabular}{|c|c|c|c|c|c|}
\hline \multicolumn{3}{|c|}{ Initial Eigenvalues } & \multicolumn{3}{c|}{ Extraction Sums of Squared Loadings } \\
\hline Total & \% of Variance & Cumulative \% & Total & \% of Variance & Cumulative \% \\
\hline 5.659 & 40.418 & 40.418 & 5.659 & 40.418 & 40.418 \\
\hline 1.367 & 9.763 & 50.181 & 1.367 & 9.763 & 50.181 \\
\hline 1.213 & 8.661 & 58.842 & 1.213 & 8.661 & 58.842 \\
\hline 1.012 & 7.232 & 66.074 & 1.012 & 7.232 & 66.074 \\
\hline
\end{tabular}

Table 6. Rotated Component Matrix

\begin{tabular}{|c|c|c|c|c|}
\hline \multicolumn{5}{|c|}{ Rotated Component Matrix ${ }^{a}$} \\
\hline & \multicolumn{4}{|c|}{ Component } \\
\hline & 1 & 2 & 3 & 4 \\
\hline LS3 & .820 & & & \\
\hline LS2 & .808 & & & \\
\hline PR3 & .746 & & & \\
\hline PR1 & .679 & & & \\
\hline PR2 & .626 & & & \\
\hline LS1 & .619 & & & \\
\hline GR1 & & .780 & & \\
\hline VO1 & & .734 & & \\
\hline GR2 & & .702 & & \\
\hline VO3 & & .514 & & \\
\hline $\mathrm{CO} 1$ & & & .779 & \\
\hline $\mathrm{CO} 2$ & & & .721 & \\
\hline $\mathrm{NC} 2$ & & & & .840 \\
\hline NC3 & & & & .719 \\
\hline \multicolumn{5}{|c|}{$\begin{array}{l}\text { Extraction Method: Principal Component Analysis. } \\
\text { Rotation Method: Varimax with Kaiser Normalization. }\end{array}$} \\
\hline Rotation conve & & & & \\
\hline
\end{tabular}


As showed in Table 7, based on the characteristics of the indicators, we used the Compute Variable function to group and create new aggregated variables to include in regression analysis in the next section.

Table 7. New aggregated variables

\begin{tabular}{|c|c|}
\hline LS3 & \multirow{6}{*}{ LS_PR } \\
\hline LS2 & \\
\hline PR3 & \\
\hline PR1 & \\
\hline PR2 & \\
\hline LS1 & \\
\hline GR1 & \multirow{4}{*}{ GR_VO } \\
\hline VO1 & \\
\hline GR2 & \\
\hline VO3 & \\
\hline $\mathrm{CO} 1$ & \multirow{2}{*}{ CONFI } \\
\hline $\mathrm{CO} 2$ & \\
\hline $\mathrm{NC} 2$ & \multirow{2}{*}{ NVERB } \\
\hline $\mathrm{NC} 3$ & \\
\hline
\end{tabular}

\subsubsection{Regression Model}

The indicators of independent variables after being grouped to create 4 new independent variables are LS_PR, GR_VO, CONFI, NVERB as above, we continue to do the same with the indicators of dependent variables to create the new dependent variable is SS. Regression analysis continues to be conducted to find the relationship between the independent and dependent variables. Data processing results are shown as the following tables.

Table 8. Model Summary ${ }^{\mathrm{b}}$

\begin{tabular}{|c|l|c|c|c|}
\hline $\mathrm{R}$ & $\mathrm{R}^{2}$ & Adjusted $\mathrm{R}^{2}$ & Std. Error of the Estimate & Durbin-Watson \\
\hline $.805^{\mathrm{a}}$ & .648 & .642 & .54990 & 1.802 \\
\hline
\end{tabular}

a. Predictors: (Constant), LS_PR, GR_VO, CONFI, NVERB

b. Dependent Variable: SS

Table 9. Coefficients ${ }^{\mathrm{a}}$

\begin{tabular}{|c|c|c|c|c|c|}
\hline \multirow{2}{*}{ Model } & \multicolumn{2}{|c|}{ Unstandardized Coefficients } & \multirow{2}{*}{$\frac{\text { Standardized Coefficients }}{\text { Beta }}$} & \multirow[t]{2}{*}{$\mathrm{t}$} & \multirow[t]{2}{*}{ Sig. } \\
\hline & B & Std. Error & & & \\
\hline (Const) & -.624 & .184 & & -3.402 & .001 \\
\hline LS_PR & .669 & .061 & .572 & 10.951 & .000 \\
\hline GR_VO & .237 & .061 & .194 & 3.846 & .000 \\
\hline CONFI & .096 & .048 & .097 & 1.998 & .047 \\
\hline NVERB & .117 & .054 & .103 & 2.187 & .030 \\
\hline
\end{tabular}


From the above results, the 4 independent variables have a positive and significant effect on the students' English speaking (SS) performance expressed in the standardized coefficient of 4 variables with positive signs. In which LS_PR variable has the strongest impact on students' speaking ability with Beta coefficient adjusted by 0.572 , while the second most powerful variable is GR_VO with only Beta adjusted by 0.194 . From the Beta value of the coefficients in Table 9, we can write the regression equation showing the ability to speak English as follows:

$$
\begin{gathered}
\mathrm{SS}=0.572 \times \mathrm{LS} \_\mathrm{PR}+0.194 \times \mathrm{GR} \text { _VO }+0.103 \times \\
\mathrm{NVERB}+0.097 \times \mathrm{CONFI}
\end{gathered}
$$

\section{Discussions}

\subsection{Focus on Improving Your Students' Listening and Pronunciation Skills}

Through data analysis, the research team found that the most powerful factor affecting students' ability to speak English was their ability to listen and pronounce. The standardized Beta coefficient is 0.572 , nearly 3 times the normalized Beta factor. The second factor is Vocabulary and Grammar. Indeed, speaking skills cannot develop unless listening skills develop [12]. Students must understand what they hear, so that conversation is successful because in communication when one person talks, the other responds through the listening process. With the same vocabulary and grammar level, students who are better at listening and pronouncing will be 3 times more likely to speak than their peers. This result is consistent with many studies conducted in the world. Feyten conducted a study to find out whether there was a link between listening ability and foreign language proficiency, between listening and listening comprehension, and between listening and speaking fluent foreign language [13]. The results show that there is a significant relationship between listening ability and foreign language proficiency; between listening and listening comprehension skills; and between listening and speaking fluent foreign languages. Bozorgian conducted a study to examine the relationships of listening skills with other language skills [14]. The results of his study show a strong correlation between listening comprehension and language proficiency. He said that the higher the listening score, the better the speaking score.

Similarly, the ability to pronounce correctly is also strongly correlated with the ability to speak English in students surveyed. First, when they pronounce correctly, the opponent will understand what they want to communicate and from there and the conversation goes smoothly. Second, when students pronounce correctly, when listening, especially in listening exams, students understand exactly what the test is referring to so that the most appropriate answer. However, the problem that the research team is interested in is that most students taking part in the survey do not know the principles of checking and reading new words. With mis-pronouncements, the lecturers rarely correct them. According to one student, "we focus on writing the main words, if the reading is wrong, the lecturers will only occasionally remind because there is no time to correct them all". In fact, students only spend very little time in every hour learning English to really listen or speak English. The amount of time students is taught to speak English in the class is minimal, and teachers do not feel the need or have no time to teach students speaking skills. They only focus on grammar, reading, and writing, not focusing on improving listening and speaking skills for students. The lack of communication skills, including pronunciation, is not yet a concern for lecturers. Therefore, in the coming time, lecturers need to focus on improving listening and speaking skills for students better.

\subsection{Guide Students to Learn Vocabulary and Grammar}

Another factor that is also related to students' ability to speak English is the vocabulary and grammar. To speak in another language, we need to have linguistic competence, we must have enough vocabulary and the syntax of that language. However, linguistic competence is still not sufficient for one person to communicate fluently in another language [15]. When taking part in in-depth interviews of some final-year students about the role of English vocabulary, many students shared that the source of English vocabulary they received was not only from English classes but also accumulated through reading materials they have access to on the internet. Some students expressed regret that they did not learn English in the first place and did not accumulate their vocabulary, so they planned to apply for jobs in small domestic companies which don't require a high level in English. However, they will try to revise English language so that after a few years when they have accumulated working experience and English capital, they will apply for positions in foreign companies.

\subsection{Build Confidence}

Besides these two factors, the research team also found that the confidence factor also correlates with students' ability to speak English. Park \& Lee also examined the relationship between anxiety, confidence, and speaking performance in 132 students. They concluded that their confidence significantly affected the speaking performance of these 132 practitioners. They say that if students are more confident, their speaking effect will be better [16]. In the opinion of many students, in the English class, students do not have the confidence to speak English, most of the conversations in the class are mainly lecturers ask and 
students answer. There is no interaction and students are often passive in conversations. Students often feel worried and nervous about lessons because they are afraid of being wrong. In the traditional classroom environment like today, lecturers play a central role and question students. The interaction of each student to all members of the class is very limited. With the fear of being afraid of mistakes, some students are terrified to speak unless forced or assigned by the lecturers.

\subsection{Improve Nonverbal Communication}

The final factor that influences students' ability to speak is nonverbal communication. Good use of nonverbal communication helps students speak English better. They feel more confident when speaking and it feels cool to know how to use appropriate gestures and actions. However, many of the students interviewed expressed that they did not know much about nonverbal communication when speaking English. Mostly, they use simple nonverbal communication and apply to many situations. Students acknowledge that this sometimes affects the effectiveness of speaking English. What the students share is true, it comes from the fact that there is no subject or special event sharing them with this knowledge and skills. Even many long-term teachers do not know how to express nonverbal communication to make the classroom, especially the English classes more vibrant and attractive.

\section{Conclusions}

Improving students' English-speaking skills is not a simple task that takes time to change foreign language learning habits that have become obsolete and no longer suitable in the new situation. The study contributed important quantitative evidence on the impact of listening and pronunciation skills on students' ability to speak English, while quantifying other groups of variables that have a significant impact on speaking ability such as Vocabulary and grammar, confidence, nonverbal communication. On that basis, the study has proposed suggestions to improve English speaking ability in students. However, because of limited time and human resources, the study was only conducted on a relatively small sample in Danang City. For further studies, the target audience may expand to other cities or countries to understand the factors affecting speaking skills that are different or not and to find out the causes.

\section{Appendix A. Constructs Measurement (5-point Likert Scale)}

\begin{tabular}{|c|c|}
\hline \multicolumn{2}{|c|}{ IV 1. LEARNING ENVIRONMENT } \\
\hline 1 & You are given enough time to practice speaking in English class \\
\hline 2 & You have enough time to prepare speaking exercises before presenting \\
\hline 3 & Listeners (teachers, friends) are patient, understand and support you when you speak English \\
\hline 4 & Instructors often help you correct mistakes made when you speak English \\
\hline 5 & Instructors always use English while teaching \\
\hline \multicolumn{2}{|c|}{ IV 2. SHAME } \\
\hline 6 & You feel nervous making mistakes while speaking English \\
\hline 7 & You feel ashamed of not speaking English well \\
\hline 8 & Feeling ashamed makes you dare not to speak English \\
\hline 9 & You feel afraid of being criticized or losing your face when you don't speak English well \\
\hline \multicolumn{2}{|c|}{ IV 3. MOTIVATION } \\
\hline 10 & You feel happy when speaking English \\
\hline 11 & You would love to speak English in English class \\
\hline 12 & You often practice speaking English outside of class time \\
\hline 13 & You think that speaking English well is necessary for future work \\
\hline \multicolumn{2}{|c|}{ IV 4. TOPICS OF INTEREST } \\
\hline 14 & When you speak English on a topic that you are familiar with or interested in, you speak better \\
\hline 15 & You like to learn English speaking skills with interesting topics \\
\hline 16 & You found that the topics covered in the English class of the school are attractive \\
\hline
\end{tabular}


Continued

\begin{tabular}{|c|c|}
\hline \multicolumn{2}{|c|}{ IV 5. VOCABULARY } \\
\hline 17 & Your English vocabulary is quite rich \\
\hline 18 & You have no trouble in communicating with your current vocabulary \\
\hline 19 & When necessary, you can find English words to speak appropriately to the context \\
\hline \multicolumn{2}{|c|}{ IV 6. CONFIDENCE } \\
\hline 20 & You believe that you can speak English fluently \\
\hline 21 & You feel confident speaking English in class \\
\hline 22 & In your opinion, confidence is essential to speak English well \\
\hline \multicolumn{2}{|c|}{ IV 7. LISTENING SKILLS } \\
\hline 23 & Your listening skills are quite good \\
\hline 24 & You can hear the basic communication situations \\
\hline 25 & When teachers ask questions in English, you can understand \\
\hline \multicolumn{2}{|r|}{ IV 8. NON-VERBAL COMMUNICATION } \\
\hline 26 & According to you, non-verbal communication (hand gestures, eyes, body ...) helps to speak English better \\
\hline 27 & You can use different types of nonverbal communication when speaking English \\
\hline 28 & Your nonverbal communication style appeals to the listener \\
\hline \multicolumn{2}{|c|}{ IV 9. ANXIETY } \\
\hline 29 & You feel pressured to speak English before class \\
\hline 30 & Sometimes you forget words or ideas when you are speaking because of anxiety \\
\hline 31 & You often slurred while speaking English because of stress \\
\hline \multicolumn{2}{|c|}{ IV 10. USE OF MOTHER TONGUE } \\
\hline 32 & You still use Vietnamese in English classes \\
\hline 33 & When you have to talk about something in English, you often think in Vietnamese \\
\hline 34 & Teachers sometimes still use Vietnamese in English classes \\
\hline \multicolumn{2}{|c|}{ IV 11. ORIENTATION } \\
\hline 35 & You think the goal of learning to speak English is to speak fluently rather than get good grades in the exam \\
\hline 36 & You think the purpose of learning English is to communicate effectively \\
\hline 37 & You believe that speaking English well will help you have better job opportunities \\
\hline \multicolumn{2}{|c|}{ IV 12. PRONUNCIATION } \\
\hline 38 & You notice your ability to pronounce pretty good \\
\hline 39 & You can pronounce vowels and consonants in English \\
\hline 40 & Your pronunciation is good enough for the listener to understand what you mean \\
\hline \multicolumn{2}{|c|}{ DV. ENGLISH SPEAKING PERFORMANCE } \\
\hline 41 & You find yourself speaking English better than others \\
\hline 42 & You can express quite well a simple problem in English \\
\hline 43 & You can speak English with little preparation time \\
\hline 44 & You are satisfied with your ability to speak English \\
\hline 45 & With your English speaking ability, you think you will have many opportunities to find suitable jobs \\
\hline
\end{tabular}

Note

IV: Independent Variable, DV: Dependent Variable 


\section{REFERENCES}

[1] Baker, J. and H. Westrup (2003). Essential speaking skills, A\&C Black.

[2] Nation, I. and J. Newton (2009). Teaching ESL/EFL Reading and Writing ESL \& Applied Linguistics Professional Series, London: Routledge.

[3] Bachman, L. F. and A. S. Palmer (1996). Language testing in practice: Designing and developing useful language tests, Oxford University Press.

[4] Ur, P. (1996). 1st published. A course in Language Teaching: Practice and Theory, Cambridge University Press.

[5] Al Hosni, S. (2014). Speaking difficulties encountered by young EFL learners. International Journal on Studies in English Language and Literature (IJSELL), 2(6), 22-30.

[6] Littlewood, W., \& William, L. (1981). Communicative language teaching: An introduction: Cambridge university press.

[7] Kumaravadivelu, B. (2003). Beyond methods: Macrostrategies for language teaching: Yale University Press.

[8] Brumfit, C. (1984). Communicative methodology in language teaching: The roles of fluency and accuracy, Cambridge University Press Cambridge.

[9] Peterson, R. A. (1994). "A meta-analysis of Cronbach's coefficient alpha." Journal of consumer research 21(2): 381-391.

[10] Nie, N., Bent, D., \& Hull, C. (1970). Statistical package for social sciences survival manual: A step by step guide to data analysis using SPSS. New York, Mc GrawHill, 343.

[11] Griffith, A. (2007). SPSS for Dummies: John Wiley \& Sons.

[12] Doff, A. (1998). Teach English: A training Course for Teacher. Cambridge University Press.

[13] Feyten, C. M. (1991). "The power of listening ability: An overlooked dimension in language acquisition." The Modern Language Journal 75(2): 173-180.

[14] Bozorgian, H. (2012). The relationship between listening and other language skills in international English language testing system. Theory and Practice in Language Studies, 2(4), 657-663.

[15] Nunan, D. (1999). Second Language Teaching \& Learning, ERIC.

[16] Park, H. and A. R. Lee (2005). L2 learners' anxiety, self-confidence and oral performance. 10th Conference of Pan-Pacific Association of Applied Linguistics, Edinburgh University, conference proceedings. 